\title{
Communicating Populism
}

Comparing Actor Perceptions,

Media Coverage, and Effects

on Citizens in Europe

\section{Edited by Carsten Reinemann, James Stanyer, Toril Aalberg, Frank Esser, and Claes H. de Vreese}

First published 2019

ISBN: 978-1-138-39272-4 (hbk)

ISBN: 978-0-429-40206-7 (ebk)

12 Adapting to the Different Shades of Populism

Key Findings and Implications for Media, Citizens, and Politics

Claes H. de Vreese, Carsten Reinemann, James Stanyer, Frank Esser, and Toril Aalberg

(CC BY-NC-ND 4.0) 
First published 2019

by Routledge

52 Vanderbilt Avenue, New York, NY 10017

and by Routledge

2 Park Square, Milton Park, Abingdon, Oxon OX14 4RN

Routledge is an imprint of the Taylor \& Francis Group, an informa business

(C) 2019 Taylor \& Francis

The right of Carsten Reinemann, James Stanyer, Toril Aalberg, Frank Esser, and Claes H. de Vreese to be identified as the authors of the editorial material, and of the authors for their individual chapters, has been asserted in accordance with sections 77 and 78 of the Copyright, Designs and Patents Act 1988.

With the exception of Chapters 1 and 12, no part of this book may be reprinted or reproduced or utilised in any form or by any electronic, mechanical, or other means, now known or hereafter invented, including photocopying and recording, or in any information storage or retrieval system, without permission in writing from the publishers.

Chapters 1 and 12 of this book is available for free in PDF format as Open Access from the individual product page at www.routledge.com. It has been made available under a Creative Commons Attribution-Non Commercial-No Derivatives 4.0 license.

Trademark notice: Product or corporate names may be trademarks or registered trademarks, and are used only for identification and explanation without intent to infringe.

Library of Congress Cataloging-in-Publication Data

A catalog record for this book has been requested

ISBN: 978-1-138-39272-4 (hbk)

ISBN: 978-0-429-40206-7 (ebk)

Typeset in Sabon

by Apex CoVantage, LLC 


\title{
12 Adapting to the Different Shades of Populism
}

\author{
Key Findings and Implications \\ for Media, Citizens, and Politics
}

\author{
Claes H. de Vreese, Carsten \\ Reinemann, James Stanyer, Frank \\ Esser, and Toril Aalberg
}

\section{Introduction}

This book started from several assumptions, the key one being that although the rise of populism can be regarded as an international trend, it may take different forms when investigated in an internationally comparative manner. This book set out to look systematically for both similarities and differences in populist political communication processes in a variety of European nations. The previous chapters presented findings from several large-scale and comparative studies of populist communication. They examined how politicians and journalists perceive populism and the role of the media and communication (Part I); populist elements in media coverage and the factors explaining their prevalence (Part II); and cognitive, attitudinal, and behavioral effects of populist communication, using cross-national survey embedded experiments (Part III).

The purpose of this concluding chapter is two-fold. On the one hand, we want to tease out and summarize the key findings of the different chapters. What do these studies tell us, collectively? On the other hand, we want to extrapolate from these findings and the current literature to offer concrete stakeholder advice to politicians, journalists, and citizens who are all confronted with the challenge of populist politics and populist messages. For discussions of the limitations of this research and future research directions, we refer the reader back to the conclusions of the individual chapters where these are discussed in detail.

\section{Key Findings}

\section{Perceptions of Populism and the Media: Contexts and Experiences Matter}

The first part of this volume took a close look at how journalists and politicians across Europe perceive populism and the role played by the media in its successes and failures. While journalists did not agree on a single 
definition of populism, they overwhelmingly saw the phenomenon as a 'negative force' having detrimental consequences for European democracies and societies, and this was especially true for countries in which populists are in government (see the chapter by Stanyer et al.). Despite the absence of a shared definition, and limited critical reflection of the term, the journalists from 13 countries could easily identify populist politicians, although some only mentioned international examples and refrained from naming domestic ones. There were no strong regional patterns of perceptions of populism or systematic differences between journalists from different types of media outlets. Rather there were commonalities in more general perceptions of populism that crossed nations, and differences in more specific questions which pointed to the relevance of specific national experiences, situations, and circumstances.

The journalists interviewed identified a number of reasons for the rise of populism. Interestingly, these causes more or less reflect the findings of the scholarly literature (e.g., Guiso, Herrera, Morelli, \& Sonno, 2017; Lucassen \& Lubbers, 2012; van Hauwaert \& van Kessel, 2018). The demand-side drivers most often mentioned were real-world, macro-level developments connected to immigration and economic issues, although they were attributed varying significance in different countries (e.g., financial crisis, influx of refugees). In addition, nationally specific issues were also mentioned, which were often described as being connected to social cohesion (e.g., religion, minorities). This, too, reflects insights from the scholarly debate. Moreover, real-world macro drivers were often seen to work alongside supply-side conditions, such as effectively communicating populist politicians who pick up 'hot' issues and capitalize on powerful emotions such as hope and fear. Interestingly, most journalists did not regard personal characteristics of politicians like charisma to be major reasons for populist success, which stands in contrast at least to some scholarly reflections on populism, but is in line with the arguments put forward in the context of the COST network (e.g., Reinemann, Aalberg, Esser, Strömbäck, \& de Vreese, 2017).

In terms of the general effect of the media on populist success, perspectives from different countries also varied a lot. While journalists from some countries perceived the media as generally supportive of populist actors and messages (Bosnia, Bulgaria, Greece, and Turkey), journalists from other countries saw them as critical (Italy, Portugal, Serbia, Spain, and France). In fact, this also corresponds well to prior theorizing and research (e.g., Esser, Stępińska, \& Hopmann, 2017). Media ownership by political actors or strong politics-media ties, a lack of strong journalist standards, and economic motives (small media markets) were mentioned most often as reasons for media support of populism (Esser et al., 2017). In addition, in countries with tabloid/popular media outlets, these were generally identified as a force promoting populism, although not all scholarly studies seem to support this in such clarity (see the chapter by Blassnig et al.). 
The cross-national investigation of how politicians in 11 countries view populism and the role of the media also made it clear that national contexts matter (see the empirical chapter by Salgado et al.). As with the journalists, the interviews did not reveal clearly discernible regional patterns and there were divergent views on the media's role in spreading or containing populism. Greater consensus was apparent, however, regarding the general perception of populism as a negative development with potentially harmful consequences for European democracies. And this also was true for the issues that were seen as promoting populist success in Europe, namely, immigration and economic hardship. Only some referred to populism as a force that could strengthen democracies by fostering political inclusion of alienated parts of the electorate and boosting political engagement. This, however, should not come as a surprise, as most of the politicians interviewed were political opponents and competitors of populist parties.

Interestingly, when asked for the reasons for populist success, politicians were rather self-reflective and mainly pointed to the malfunctioning of established democratic institutions, including mainstream political parties, in addressing problems and producing convincing discourses and solutions. In contrast to that, politicians, like the journalists interviewed, did not see a strong contribution of individual personalities and charisma as a driving force for the attractiveness and success of populism, which stands in contrast to parts of the literature (see Reinemann et al., 2017 for a discussion). In fact, politicians were likely to see social developments and deficits on the part of the established political institutions to be more important.

With respect to the role of the media, both mainstream news and social media, politicians generally agreed that they are an important part of the equation to explain populist success. In contrast, politicians in some countries suggested that the news media were regularly instrumentalized by their populist governments. On the other hand, media competition and commercialization were mentioned as driving factors that contribute to a tabloidization of news-making, which was seen as enhancing the chances of populist messages and actors being covered. This, again, is very much in line with the arguments put forward in the literature on the interplay between populism and the politicized or commercialized media (see also Part II of this volume). Moreover, politicians regard social media as conducive to populist success because of the opportunities they provide for populists in particular to bypass the traditional news media, which is, again, quite similar to the arguments put forward in the scholarly debate (e.g., Engesser, Fawzi, \& Larsson, 2017).

Politicians and journalists thus share the analysis of immigration and economic hardship as factors fostering populism and when these are salient, individually or in combination with each other, they are conducive to populist success. They also agree in that they do not see strong regional 
patterns, i.e., they did not refer to consistent patterns in, for example, Southern or Eastern Europe. Rather they see either overarching international trends or national-level factors as more important in explaining populist success and the role of the media. Interestingly, politicians and journalists seem to differ somewhat in their interpretation of the role of the media. Politicians tend to consider the media as central actors and also part of explaining populist success, while journalists tend to not see the media as playing a significant role in the rise of populism. This difference squares well with several studies comparing perceptions of journalists and politicians of the role of the media in democratic processes (e.g., Vliegenthart \& Skovsgaard, 2017; but also see Fawzi, 2018a). In connection to populism, these differences may also be indicative of a problematic unwillingness of journalists to accept the fact that they may unwittingly support populist agendas and rhetoric by, for example, promoting certain issues or applying certain frames. We will get back to this point below.

\section{Populism in Media Coverage: Contextual and Organizational Drivers}

The book also reports the findings of a cross-national content analysis of a variety of print news media in 12 European countries. Focusing on immigration coverage and opinion pieces, the chapters give a comprehensive overview of where populist messages are most common and who are their sources (see the chapter by Blassnig et al.). In addition, they identify important drivers of the presence of these populist elements on the macro, meso-, and story level (see the chapters by Maurer et al. and Esser et al.).

In line with the results from the interviews with politicians and journalists, the chapter by Blassnig et al. concludes that there obviously are important national peculiarities with regard to populist messages in the media. For example, in line with prior theorizing, results suggest that 'the people' and respective out-groups are defined somewhat differently in different countries. For instance, in some countries, the media convey a more cultural or religious notion of 'the people' and 'the others' (e.g., Poland, Israel, Bulgaria). In addition, although anti-elitism was the most common dimension of populism in media coverage, countries differed in which elites were the most frequently criticized (e.g., national, supranational, or the media elite). Moreover, the relative presence of the in- vs. outgroup-oriented dimensions of populism varied, too. In contrast to that, a common feature of coverage across most countries was that higher levels of people-centrist messages usually went along with higher levels of exclusionary messages. This suggests that media coverage typically contributes to perceptions of an antagonism between in- and out-groups once people-centrist or exclusionary messages become more frequent in the news. This finding supports the interviewed politicians' perception that the mass media do initiate the dissemination of populist ideas. 
Moreover, the analyses by Blassnig et al. show that there is considerable cross-country variance in the presence of individual dimensions of populism as well as different patterns of how those dimensions stand in relation to one another. This highlights the importance of the chapter by Maurer et al., which takes a closer look at several macro- and meso-level factors that might encourage, or dampen, the presence of populist elements in media coverage. Regarding macro-level factors, their analyses show significant relationships between the role perceptions journalists typically hold in a country and the degree of populism in its newspapers. In countries where journalists emphasize an educational role, degrees of populism tend to be lower, suggesting that journalists may have the aim to shield their audiences from populist messages. The opposite holds true for countries in which journalists typically lean towards more supportive or adversarial role conceptions. Where journalists perceive themselves as facilitators of governments (supportive role), regular news coverage includes more populist messages, indicating a greater extent of populism through the media. Where journalistic culture is more adversarial there also is more (anti-elite) populism, especially in editorials and commentaries. This suggests a greater degree of populism by the media in these contexts, i.e., the media taking a more political role themselves (e.g., Hanitzsch, 2007; Hanitzsch \& Vos, 2018).

Regarding meso-level, organizational factors, Maurer et al. do not find evidence that tabloid newspapers per se tend to include more populist messages. This is in line with some prior studies but stands in contrast to others (Wettstein, Esser, Schulz, Wirz, \& Wirth, 2018). In the data analyzed here, the mass-market orientation of media organizations in itself did not generally foster populist messaging. The authors conclude that it rather is the preference for a news logic that emphasizes political conflict and emotional cues, which creates favorable conditions for populist content. Clearly, more research is needed to disentangle the interactions between populists and tabloid/commercial media as well as the countryspecific factors that seem to have a crucial impact on the exact functioning of this relationship and the part played by tabloid media.

In contrast to the previous chapters, the analyses by Esser et al. applied a dynamic perspective and compared the presence of populist message elements in newspaper coverage in 2016 and 2017. The primary goal of this analysis across time was to investigate the relationship between certain macro-level situational factors (i.e., migration, political activities, audience perceptions of issues) and changes in the degree of populism as reflected in news coverage. Again, results suggest a high degree of countryspecificity and the authors conclude that intra-media factors seem to be the most important explanatory factors for the changes of populist reporting between 2016 and 2017. However, there also is at least some indication that contextual and situational factors also affected populism in news coverage, although different factors were influential in different national 
contexts. For example, the degree of populism in the news was obviously connected to the actual development of migration in some countries (e.g., Germany and Greece; event-driven) while in others it seemed to be more politics-driven (e.g., Bulgaria, Poland). In contrast to that, there was no evidence for a strong effect of the public agenda, which would have been indicative of audience-driven news.

\section{Effects of Populist Communication: Identity, Deprivation, and the Blame Game}

Turning to the effects of populist communication, the theoretical chapter by Hameleers et al. provides a conceptual framework and then the methodological chapter by Hameleers, Andreadis, and Reinemann lays out the design of a cross-national experiment. The conceptual chapter integrates research on selective exposure, motivated reasoning, social identity, cognitive priming, stereotyping, and blame attribution. It argues that the effects of populist communication are the result of the combination of crisis and group-related rhetoric. As a result, populist messaging entails cognitive (perceptions of crisis and deprivation), emotional (fear, in-group attachment, out-group anger), attitudinal (images of in- and out-groups), and sometimes behavioral consequences (engagement, voting). Remarkably, populist communication does not need to change attitudes, because it works by priming and trait activation only. However, not everybody will be attracted to populist messaging under any kind of real-world circumstances. Instead, its effects are conceptualized as individually differential and context-dependent. Following this theoretical outline, the following chapters investigated effects of populist messaging using a largescale experiment conducted in 15 European countries. In the experiment, respondents were shown different versions of a crisis story. The versions only differed in which groups were blamed for the future economic downfall described in the story, reflecting various kinds of empty left-wing and right-wing populism.

Corbu et al. investigated cognitive effects of the stories on blame attributions and stereotyping. These were rather weak in general, which should come as no surprise given that respondents were presented just one article that was supposed to make a difference. However, the analysis was able to show that left-wing anti-outgroup cues blaming 'the rich' and economic elites were most influential, that the impact of anti-immigrant cues was much weaker, and that both anti-politics and people-centrism cues made almost no difference. The reasons for these differential effects seem to be complex. For the effects of the left-wing out-group cues, the fit of the specific issue (economy) and the blamed out-group ('the rich') was probably crucial, whereas blaming immigrants might not be regarded especially credible in the economic context of the story. This may have contributed to the finding that anti-immigrant cues did not increase immigrant 
blaming in most countries-and even backfired in some contexts (e.g., Sweden).

In contrast to that, the limited effects of anti-politics cues are most likely the result of a ceiling effect: because blaming politicians was so common and their image so negative across countries, the chances of significant additional negative effects were rather small. And, finally, the fact that people-centrism cues were not influential by themselves might be traced back to the fact that negative appeals (blame) are generally more persuasive. Although these explanations need further investigation, the results more broadly suggest that blaming strategies need to fit the thematic issue context in which they are used, because citizens seem to see through overly transparent attempts to blame groups that can hardly seriously be called out as responsible.

With respect to the impact of contextual factors, the analyses by Corbu et al. again support the notion that the exact functioning of populist communication seem to be rather country-specific. In addition, although the idea of regional differences may seem appealing at first sight, the data do not suggest that regional differences are clear-cut or even important. This supports both findings from the interviews with journalists and politicians, as well as results of the content analysis presented in Parts I and II of this volume.

Finally, Andreadis et al. investigated effects of populist cues on populist attitudes and voting intentions. Generally, effects were again rather small. But given that this effect can be expected to be conditional on individual characteristics and national contexts, it is rather striking that a single stimulus had any impact at all. Against this background, the effects that Andreadis et al. find of people-centrism, anti-immigrant, and leftwing anti-outgroup cues ('the rich') on people-centrism and anti-wealthy attitudes, respectively, should neither be over-interpreted nor completely neglected. Again, results were very country-specific with almost no clear regional trends apparent. In some countries, none of the populist cues had any impact on the different dimensions of populist attitudes (i.e., Norway, Sweden, France, Austria, and Israel) while in others there were specific cues that resonated with the audience. For example, people-centrism cues boosted people homogeneity attitudes in Italy and Spain, left-wing anti-outgroup cues negatively affected attitudes toward the wealthy in Germany, the Netherlands, Poland, Spain, and the UK, and right-wing anti-out-group cues activated anti-immigrant attitudes in Italy and Greece.

As far as voting intentions are concerned, at least one of the cues had an effect on populist voting in five of the 15 countries (Greece, Norway, Romania, Sweden, and Switzerland). Remarkably, although the antiimmigrant cue did not produce strong cognitive effects in the analysis by Corbu et al., it had the strongest impact on voting for right-wing populist parties in Norway. In addition, effects were found of anti-elite cues on left-wing populist voting (Switzerland); of people-centrism cues 
on left-wing (Romania) and right-wing populist voting (Sweden); and of anti-wealthy cues on right-wing populist voting (Greece, Romania). This shows that, depending on the national contexts, the same kinds of populist cues might benefit different kinds of populists parties. This is in line with recent research (e.g., Rooduijn \& Burgoon, 2018).

\section{General Conclusion From the Empirical Studies}

In sum, there are no simple and across-the-board conclusions about the workings of populist communication across Europe. This is an important antidote to the pervasive naïve, universalist narrative about populism (see also de Vreese, Esser, Aalberg, Reinemann, \& Stanyer, 2018). Although economic issues and the societal and political discussion about immigration and integration can generally be regarded as conducive to populist success, the dynamics and patterns of populist communication and how it is covered and perceived still seem to be strongly affected by national contexts. For example, although the cross-national analysis of news coverage points to the fact that the most important role of the media generally is to provide a platform for populists, some media seem to take a more active and political approach, probably crossing the line and becoming populist actors at times.

The book also highlights that media effects on citizens can be found, but that these appear to be contingent on whether certain messages are repeated (which they were not in our experimental design), whether or not certain predispositions are already strongly held (such as in our case where ceiling effects kicked in), and whether or not the effects are expected across the board or only for some citizens and in some regions or contexts. Perhaps it is encouraging to see that citizens are not swayed massively in their responses to a single stimulus material.

\section{Implications}

Based on the book's findings, the state-of-the art literature, and ongoing public and academic discussions about the responses to populism by politicians, journalists, and citizens, we want to offer some guidance in this final section to everybody faced with today's populist political communication. We realize that advice already exists in the public domain, but we provide it from the perspective of the countries covered here, mostly European democracies, and acknowledge that giving advice often means overlooking some national nuances. For example, reactions to populism in countries where populist parties are in government, have privileged access to public service media, or even have their own media organizations may well be different from reactions in countries where populist parties are rather small and put a stronger focus on bypassing traditional 
news media via online channels. In addition, reactions to populist parties will also depend on whether they share basic democratic values or whether they (at least partially) cross the line to authoritarian or even extremist positions (e.g., Abts \& Rummens, 2007). We nevertheless feel compelled to extrapolate the following lessons from extant research and the findings of this book.

\section{Journalists and the Media ${ }^{1}$}

\section{Reflect on Your Role and Be Transparent About It}

The results of the content analysis have shown that there seems to be a connection between journalistic role conceptions and how populism is reflected in the news. In fact, various discussions with journalists also seem to indicate that the great uncertainty about how to deal with populists often is related to a more general insecurity about journalism's role in a liberal democracy under pressure. Therefore, a necessary step for journalists and media organizations is to reflect on their values and their role in democracy. Are they more or less passive conveyors of information? Is there a point where they feel compelled to explicitly defend democratic values or warn against certain actors? What will be the result of the position we take and the coverage we base on these decisions? These are important questions that media organizations need to answer for themselves, and that they need to be transparent about vis-à-vis their audiences.

\section{Use the Same Standards for Populists and Non-Populists}

Representatives and voters of populist parties are especially critical of the established news media (e.g., Fawzi, 2018b; Schulz, Wirth, \& Müller, 2018). Neglecting, isolating, or judging populist parties by different standards might therefore strengthen anti-media sentiments and even contribute to their political success. Belgium's Vlaams Blok party is a case in point. The party was neglected by political opponents and the media, and it gained popularity in the wake of criticism of the established parties and elite media (Coffé, Heyndels, \& Vermeir, 2007). Journalists should therefore cover populist actors based on the same standards they use for other political actors.

\section{Call Out Populists When Democratic Norms Are Violated}

Although this may to a certain degree depend on the role conception journalists identify with, we are convinced that journalists generally need to call out populists on norm violations and give voice to critics when 


\section{Claes H. de Vreese et al.}

foundations of liberal democracy (e.g., separation of powers, rule of law, religious freedom, minority rights, freedom of speech and the press) are challenged-or when populist parties (or parts of them) cross the line toward extremism. Indeed, calling populists out in these cases can be an effective tool to reduce their legitimacy among potential voters (van Spanje, 2018). As aptly put by Michael Schudson (1995, p. 217), this represents more than just accountability to the voters: 'The press can serve as a stand-in for the public, holding governors accountable-not to the public (which is not terribly interested), but to the ideas and rules of the democratic polity'.

\section{Fact-Check and Correct}

One of the keys to populist success is its ability to cultivate the perception that crisis and decline are imminent and that certain groups are to blame. If the real-world situation does not justify this portrayal, populists may make use of misinformation, disinformation, and misleading characterizations of reality. In fact, there is some indication even beyond Donald Trump that populist actors may be especially tempted to use misinformation and fall victim to argumentative fallacies (Bergmann, 2018; Blassnig, Büchel, Ernst, \& Engesser, 2018). Because of that it is important to be aware of the results of research on corrections, which indicates that although 'backfire effects' may happen, especially among strong partisans, corrections do generally reduce misperceptions (e.g., Chan, Jones, Hall Jamieson, \& Albarracín, 2017; Walter \& Murphy, 2018). This makes fact-checking and correction important tools when scrutinizing the foundations of populist blaming and issue positions. Corrections of populist-originated misinformation and disinformation then should be done in a matter-of-fact way, ideally provide substantial explanations, and use sources that are close to populist positions ideologically. This suggestion also refers to cases in which populists present themselves as representing 'the will of the majority'. Journalists should check those claims, too, and be aware of 'false equivalence' where some viewpoints held by de facto minorities end up getting as much media attention as de facto majorities and appear to represent 'the will of the people'.

\section{Ask for Details, Foundations, and Consequences}

When covering populist actors, like any political actors, attention to the details, foundations, and consequences of (policy) proposals is imperative. The watchdog function and scrutiny should apply to all (see above). Insisting on explanation and justification can be daunting, but it is the only way to discover whether populist proposals are realistic or adequate, what kind of values and ideas they are based on, whether their portrayal 
of reality and the blame they attribute is justified, and what consequences their proposals would entail.

\section{Beware of Populism Through the Media and Do Not Fall for Their Strategies of Provocation}

Although often critical, populists, too, have an interest in getting their message across in the news media. Sometimes they exploit journalists and media logic by using tactics of provocation, taboo breaking, and strategic ambiguity to change and dominate the media agenda or change it to their advantage (e.g., Gutsche, 2018; Krämer, 2018). Although messaging by elite actors or political parties is potentially newsworthy, journalists have to be aware of the fact that they might inadvertently become a crucial part of party communication and success if they only adhere to a passive role conception and fall for every outrageous statement or unimportant proposal. Journalists should have in mind that sometimes statements may be deliberately designed to cause outrage and therefore may also want to try to explicitly de-mask this strategy and the motives behind it.

\section{Beware of Populism by the Media}

Research has shown that populist actors-like other political actors-may not only benefit from coverage of themselves, but also from coverage of the issues they 'own' as well as overly critical coverage of established parties and the established political system (e.g., Wirz et al., 2018). We can assume that this is especially true when media coverage becomes media populism, i.e., when the media use the same crisis narratives, people-centrism, and blame frames, the same overly generalizing 'us vs. them', anti-elite, and anti-outgroup perspectives that are characteristic of populist communication (e.g., Krämer, 2014; Esser et al., 2017). Use of these kinds of frames may (unwillingly) contribute to populist politicians' success without even mentioning populist actors at all.

\section{Be Aware of Bypassing and Digital Tribalism}

In the coverage of politics in general and populists in particular, there should be an awareness that audiences might get an increasing share of their information from political actors directly (Engesser et al., 2017). In addition, audience worldviews might increasingly be affected by (online) sources which may not care about journalistic standards or the truth, but for whom allegiance to their (digital) 'tribe' is key. If established media do not take these alternative sources seriously, an increasing gap may appear between the world that is presented in alternative and established sources, which may in the long-term damage the credibility of all information and journalistic media in particular. 


\section{Citizens}

Use news! There is a growing divide in today's high-choice media landscape between citizens that consume news and those who do not (e.g., Hopmann, Wonneberger, Shehata, \& Jonas, 2016; Strömbäck, Djerf-Pierre, $\&$ Shehata, 2013). News media consumption is unequivocally related to political knowledge, political interest, and political efficacy, all hallmarks of an engaged citizenry. In high-choice media democracies, there is abundant choice, but also a responsibility to be informed. Ignorance is no excuse.

\section{Be Willing to Pay for News}

Public information, news, and current affairs analyses are not only foundational elements of a healthy democracy, they are also commodities, and their producers are in search of viable funding models (e.g., Reuters, 2018). Quality news is costly and requires citizens paying directly through subscriptions or indirectly through taxes or license fees. A strong, independent, autonomous public broadcaster also correlates with political knowledge and interest (Fraile \& Iyengar, 2014). But it does not come for free. Therefore, it should be self-evident for citizens to be willing to pay their share for upholding institutions that are providing journalism in the public interest.

\section{Be Cognizant of Your Perceptual Screens,} Filter-Bubbles, and Echo Chambers

In a high-choice information environment there is a greater need for citizens to become aware of the information diet they select and the information diet that is automatically selected for them (through algorithms and digital behavioral traces). Citizens should be aware of the fact that their own media behavior and algorithms might put them in an echo chamber and disconnect them from other people in society—even though it is still disputed how widespread and dangerous this phenomenon may actually be (e.g., Möller, Trilling, Helberger, \& van Es, 2018; Zuiderveen Borgesius et al., 2017). Likewise, citizens should be aware that their predispositions, political preferences, and perceptual biases impact on the way they interpret new information. It is important in increasingly fragmented political and media environments to assess substance and merits of information and arguments and not accept them because they confirm pre-existing individual or tribal beliefs.

\section{Communicate Responsibly Yourself}

In today's environment, the ability to express yourself and share and like information has two important consequences: such behavior is an 
important part of citizens' public life, their self-presentation, and how their network becomes informed. Not all citizens consume and share public information like news in the same way (Allcott \& Gentzkow, 2017). In addition, the way citizens deal with news and information, particularly online, is also feeding directly into an environment where clicks, shares, and likes might (indirectly) affect subsequent news supply. In analogy to environmental behavior, citizens also have a responsibility to consider their potential information pollution and 'informational footprint'. This means, for example, to use credible news sources, become media literate, and refrain from spreading false and misleading information.

\section{Politicians}

\section{Stand Your Ground: Avoid Expedient Policy Shifts}

The literature has pointed to several consequences of the success of populist and radical right-wing parties. A recent study convincingly demonstrates that one of the biggest impacts of populist parties is to move the policy positions of mainstream parties (see Abou-Chadi \& Krause, 2018). These authors show that both mainstream left and mainstream right parties move their own policy positions in response to the success of right-wing populist parties. This highlights the need for parties to be cognizant of their own moves, since not only citizens respond to these parties, but so do mainstream parties. They should be aware of the fact that rhetorical convergence and policy shifts towards populists may not have the consequences they anticipate but rather benefit them by lending credibility and legitimacy to their claims (but see van Spanje \& de Graaf, 2018).

\section{Do Not Attack the Free Media}

Attacking and discrediting the institution of the free press is a common denominator of populist political actors. But even if many mainstream politicians are distrustful of the media, too, and find that journalists intervene and interpret too much what goes on in politics (Brants, de Vreese, Möller, \& van Praag, 2010), attacking free media only yields short-term gains. A healthy democracy is dependent upon a free press. Moreover, trust in the media and trust in politics go hand in hand. If politicians undermine public trust in the media, this will backfire on trust in their own institutions (Hanitzsch, van Dalen, \& Steindl, 2017; Fawzi, 2018b). Politicians should therefore stand out for supporting rather than undermining this core institution of liberal democracies. There is an important difference between warranted criticism and attempts to systematically undermine the credibility of the media. 
Be Cautious About Claiming to Represent

the Will of the People

At the core of representative politics is the legitimacy of the elected. It is therefore not novel in politics that politicians articulate and appeal to the voters and 'the people'. However, politicians are well advised to be specific about who they represent, and on the basis of what? Votes, polls, gut feelings? Politicians should be cognizant of the limits of certain polls and social media utterances as reflecting public opinion or the will of the people. Moreover, they should be careful when interpreting a poll conducted in the absence of a public debate. Polls without a public debate may look like public opinion and the will of the people but are often not. Moreover, caution is warranted by politicians: A key feature of modern societies is their pluralism and diversity. Creating the impression that there is one homogeneous, common will of 'the people' that can easily be understood and represented implies neglecting this de facto diversity of interests and opinions.

\section{Do Not Avoid the Debate}

When new political entrepreneurs and parties enter and alter existing party competition, established (mainstream) parties are, de facto, forced to respond. Excluding, neglecting, or ostracizing new political actors and parties is generally not a good idea (van Spanje, 2017). So at least as long as parties do not cross the line to extremism, engage and embrace them as part of the political system and arena, argue back, resist the temptation to exaggerate, and de-mask overly simplistic arguments. As a crisis narrative is the very basis of populist communication, questioning the diagnosis in the first place can be crucial. Are things really as bad as they seem? And even if they are, the values and mindset behind policy proposals as well as their likely consequences may still be debated. In doing so, be considerate of terms and frames used. Consider whether an argument is best thought of using your opponent's or your own terminology.

\section{Acknowledge the Emotional Citizen And Citizens' Emotions}

It is well known that emotionalized blame attributions influence the perception of blame and citizens' populist attitudes (Hameleers, Bos, \& de Vreese, 2017). While such use of emotional language might thus be an advantage overall, the appeal of emotions has an additional component. The raised and sustained success of populism hinges on perceptions of economic hardship and immigration. Politicians must therefore not only address the 'rational citizen', but recognize that politics is also about emotions. Acknowledging citizens' emotions, such as fear and feelings of deprivation, and understanding and helping to address these concerns 
rather than condemning their relevance are important response strategies for politicians.

\section{$* * *$}

With this book we have attempted to push the agenda on populist political communication. The academic research agenda we presented here is comparative in nature. Elsewhere (de Vreese et al., 2018, p. 424) we have argued that 'only comparative analysis can reveal and explain similarities and differences in the communicative aspects of populism across countries'. Furthermore, we believe that future research must broaden the scope of what is considered media. In this book we showcased the platform function, but the media ecology is changing, with new actors and players in the field. These actors, including major social media platforms, should be central in further analyses. But they should not be looked at in isolation, but rather as part of a larger information system, in which social media and their users interact with traditional news media and political actors in ever faster news cycles. At the same time, we still know too little about key features of social media communication in the context of populism when it comes to, for example, visuals, patterns of sharing and liking, the relevance of bots and trolls, or the extent of personalization and disinformation (de Vreese et al., 2018).

Finally, we encourage scholars to not only look at the effects of news and information. Many citizens have a preference for other formats or genres altogether (Prior, 2007). It seems relevant to expand the scope to, for example, the role of satire and political entertainment more broadly (Boukes et al., 2015). There is some evidence to suggest that satirical formats can exacerbate confirmation biases, such that satirical information options lead to less counter-attitudinal exposure (compared to hard news), thus potentially reinforcing opinions and leading to further polarization (Stroud \& Muddiman, 2013). How such processes affect selection and effects vis-à-vis populism remains an open question.

In closing, we stress again that this is not an academic endeavor alone. The topic of our research touches the very foundations of liberal democracies and all actors-whether politicians, individual journalists, media organizations, or citizens-need to be aware of and act on the basis of what we know about populist communication. At the end of the day, the quality of democracy is in great part a function of the quality of this communication and the interaction between different actors and groups.

\section{Note}

1. Some of the recommendations to journalists/media have already been discussed in de Vreese (2017). 


\section{References}

Abou-Chadi, T., \& Krause, W. (2018). The causal effect of radical right success on mainstream parties' policy positions: A regression discontinuity approach. British Journal of Political Science. Advanced online publication. doi:10.1017/ S0007123418000029

Abts, K., \& Rummens, S. (2007). Populism versus democracy. Political Studies, 55(2), 405-424. doi:10.1111/j.1467-9248.2007.00657.x

Allcott, H., \& Gentzkow, M. (2017). Social media and fake news in the 2016 election. Journal of Economic Perspectives, 31(2), 211-236. doi:10.3386/w23089

Bergmann, E. (2018). Conspiracy \& populism: The politics of misinformation. London: Palgrave Macmillan.

Blassnig, S., Büchel, F., Ernst, N., \& Engesser, S. (2018). Populism and informal fallacies: An analysis of right-wing populist rhetoric in election campaigns. Argumentation Advanced online publication. doi: 10.1007/s10503-018-9461-2

Boukes, M., Boomgaarden, H. G., Moorman, M., \& de Vreese, C. H. (2015). Political news with a personal touch: How human interest framing indirectly affects policy attitudes. Journalism and Mass Communication Quarterly, 92(1), 121-141. doi:10.1177/1077699014558554

Brants, K., de Vreese, C. H., Möller, J., \& van Praag, P. (2010). The Real Spiral of Cynicism? Symbiosis and mistrust between politicians and journalists. International Journal of Press/Politics, 15(1), 25-40. doi:10.1177/1940161209351005

Chan, M. S., Jones, C. R., Hall Jamieson, K., \& Albarracín, D. (2017). Debunking: A meta-analysis of the psychological efficacy of messages countering misinformation. Psychological Science, 28(11), 1531-1546. doi:10.1177/0956797617714579

Coffé, H., Heyndels, B., \& Vermeir, J. (2007). Fertile grounds for extreme rightwing parties: Explaining the Vlaams Blok's electoral success. Electoral Studies, 26(1), 142-155. doi:10.1016/j.electstud.2006.01.005

de Vreese, C. H. (2017). Political journalism in a populist age. Shorenstein Center: Harvard University.

de Vreese, C. H., Esser, F., Aalberg, T., Reinemann, C., \& Stanyer, J. (2018). Populism as an expression of political communication content and style: A new perspective. The International Journal of Press/Politics, 23(4), 423-438. doi:10.1177/1940161218790035

Engesser, S., Fawzi, N., \& Larsson, A. O. (2017). Populist online communication: Introduction to the Special Issue. Information, Communication \& Society, 20(9), 1279-1292. doi:10.1080/1369118X.2017.1328525

Esser, F., Stępińska, A., \& Hopmann, D. (2017). Populism and the media: Crossnational findings and perspectives. In T. Aalberg, F. Esser, C. Reinemann, J. Strömbäck, \& C. de Vreese (Eds.), Populist political communication in Europe (pp. 365-380). New York, NY: Routledge.

Fawzi, N. (2018a). Beyond policy agenda-setting. Political actors' and journalists' perceptions of news media influence across all stages of the political process. Information, Communication and Society, 21(8), 1134-1150. doi:10.1080/ 1369118X.2017.1301524

Fawzi, N. (2018b). Untrustworthy news and the media as 'enemy of the people'? How a populist worldview shapes recipients' attitudes toward the media. The International Journal of Press/Politics. Advanced online publication. doi:10.1177/1940161218811981 
Fraile, M., \& Iyengar, S. (2014). Not all news sources are equally informative: A cross-national analysis of political knowledge in Europe. The International Journal of Press/Politics, 19(3), 275-294

Guiso, L., Herrera, H., Morelli, M., \& Sonno, T. (2017). Demand and supply of populism. CEPR Discussion Paper DP11871. Retrieved from the University Bocconi website ftp://ftp.igier.unibocconi.it/wp/2017/610.pdf

Gutsche, R. E. Jr. (2018). Trump and the media. Digital Journalism. Advanced online publication. doi:10.1080/21670811.2018.1530064

Hameleers, M., Bos, L., \& de Vreese, C. H. (2017). 'They did it': The effects of emotionalized blame attribution in populist communication. Communication Research, 44(6), 870-900. doi:10.1177/0093650216644026

Hanitzsch, T. (2007). Deconstructing journalism culture: Towards a universal theory. Communication Theory, 17, 367-385. doi:10.1111/j.1468-2885.2007.00303.x

Hanitzsch, T., van Dalen, A., \& Steindl, N. (2017). Caught in the Nexus: A comparative and longitudinal analysis of public trust in the press. The International Journal of Press/Politics, 23(1), 3-23. doi:10.1177/1940161217740695

Hanitzsch, T., \& Vos, T. P. (2018). Journalism beyond democracy: A new look into journalistic roles in political and everyday life. Journalism, 19(2), 146-164. doi:10.1177/1464884916673386

Hopmann, D. N., Wonneberger, A., Shehata, A., \& Jonas, H. (2016). Selective media exposure and increasing knowledge gaps in Swiss referendum campaigns. International Journal of Public Opinion Research, 28(1), 73-95. doi:10.1093/ ijpor/edv002

Krämer, B. (2014). Media populism: A conceptual clarification and some theses on its effects. Communication Theory, 24, 42-60. doi:10.1111/comt.12029

Krämer, B. (2018). Populism, media, and the form of society. Communication Theory. Advanced online publication. doi:10.10973/ct/qty017

Lucassen, G., \& Lubbers, M. (2012). Who fears what? Explaining far-rightwing preference in Europe by distinguishing perceived cultural and economic ethnic threats. Comparative Political Studies, 45(5), 547-574. doi:10.1177/0010414011427851

Möller, J., Trilling, D., Helberger, N., \& van Es, B. (2018). Do not blame it on the algorithm: An empirical assessment of multiple recommender systems and their impact on content diversity. Information, Communication \& Society, 21(7), 959-977. doi:10.1080/1369118X.2018.1444076

Newman, N., Fletcher, R., Kalogeropoulos, A., Levy, D., \& Kleis Nielsen, R. (2018). Digital news report 2018. Oxford University: Reuters Institute.

Prior, M. (2007). Post-broadcast democracy: How media choice increases inequality in political involvement and polarizes elections. Cambridge, NY: Cambridge University Press.

Reinemann, C., Aalberg, T., Esser, F., Strömbäck, J., \& de Vreese, C. H. (2017). Populist political communication: Toward a model of its causes, forms, and effects. In T. Aalberg, F. Esser, C. Reinemann, J. Strömbäck, \& C. H. de Vreese (Eds.), Populist political communication in Europe (pp. 12-25). New York, NY: Routledge.

Rooduijn, M., \& Burgoon, B. (2018). The paradox of well-being: Do unfavorable socioeconomic and sociocultural contexts deepen or dampen radical left and right voting among the less well-off? Comparative Political Studies, 51(13), 1720-1753. doi:10.1177/0010414017720707 
Schudson, M. (1995). The power of news. Cambridge, MA: Harvard University Press.

Schulz, A., Wirth, W., \& Müller, P. (2018). We are the people and you are fake news: A social identity approach to populist citizens' false consensus and hostile media perceptions. Communication Research. Advanced online publication. doi:10.1177/0093650218794854

Strömbäck, J., Djerf-Pierre, M., \& Shehata, A. (2013). The dynamics of political interest and news media consumption: A longitudinal perspective. International Journal of Public Opinion Research, 25(4), 414-435. doi:10.1093/ ijpor/eds018

Stroud, N. J., \& Muddiman, A. (2013). Selective exposure, tolerance, and satirical news. International Journal of Public Opinion Research, 25(3), 271-290. doi:10.1093/ijpor/edt013

Van Hauwaert, S. M., \& van Kessel, S. (2018). Beyond protest and discontent: A cross-national analysis of the effect of populist attitudes and issue positions on populist party support. European Journal of Political Research, 57(1), 68-92. doi:10.1111/1475-6765.12216

Van Spanje, J. (2017). Controlling the electoral marketplace. How established parties ward off competition. Basingstoke: Palgrave Macmillan.

Van Spanje, J., \& Azrout, R. (2018). Tainted love: How stigmatization of a political party in news media reduces its electoral support. International Journal of Public Opinion Research. Advanced online publication. doi:10.1093/ijpor/ edy009

Van Spanje, J., \& de Graaf, N. D. (2018). How established parties reduce other parties' electoral support: The strategy of parroting the pariah. West European Politics, 41(1), 1-27. doi:10.1080/01402382.2017.1332328

Vliegenthart, R., \& Skovsgaard, M. (2017). Too powerful or just doing their job? Explaining differences in conceptions of media power among politicians and journalists. In P. Van Aelst \& S. Walgrave (Eds.), How political actors use the media: A functional analysis of the media's role in politics (pp. 85-103). Cham, Switzerland: Palgrave Macmillan. doi:10.1007/978-3-319-60249-3_5

Walter, N., \& Murphy, S. T. (2018). How to unring the bell: A meta-analytic approach to correction of misinformation. Communication Monographs, 85(3), 423-441. doi:10.1080/03637751.2018.1467564

Wettstein, M., Esser, F., Schulz, A., Wirz, D. S., \& Wirth, W. (2018). News media as gatekeepers, critics, and initiators of populist communication: How journalists in ten countries deal with the populist challenge. The International Journal of Press/Politics, 23(4), 476-495. doi:10.1177/1940161218785979

Wirz, D. S., Wettstein, M., Schulz, A., Müller, P., Schemer, C., Ernst, N., . . . Wirth, W. (2018). The effects of right-wing populist communication on emotions and cognitions toward immigrants. The International Journal of Press/ Politics, 23(4), 496-516. doi:10.1177/1940161218788956

Zuiderveen Borgesius, F. J., Trilling, D., Möller, J., Bodó, B., de Vreese, C. H., \& Helberger, N. (2016). Should we worry about filter bubbles? Internet Policy Review, 5(1). doi:10.14763/2016.1.401 